\title{
PENGEMBANGAN SOLAR PANEL DAN INVERTER SEBAGAI ALAT UNTUK CHARGING BATERAI PADA SEPEDA LISTRIK
}

\author{
Eko Prianto ${ }^{1}$, Sigit Yatmono ${ }^{2}$, Andik Asmara ${ }^{3}$ \\ ${ }^{1,2,3}$ Dosen Jurusan Pendidikan Teknik Elektro FT UNY \\ Email : eko_prianto@uny.ac.id
}

\begin{abstract}
This research aims to design a battery charging system using an inverter as a provider of electrical energy in the Electric Bicycle, find out the performance and effectiveness of charging the battery using an inverter compared with the system that has been installed. The method used in this research is Research and Development by developing battery charging system using inverter on commercial electric bike (SLN) that has been made. The results showed that charging the commercial Electric Bicycle has a more effective value and faster battery charging process using an inverter in a 300wp solar panel that is used as its main energy supply. The battery charging system using an inverter as a provider of electrical energy in the SLN takes 10,182 hours to charge 48 volts to full. So the process of charging the battery using an inverter is more effective than the system that has been previously installed with a ratio of charging the battery of 1: 2.94 or three times more effective than the previous system.
\end{abstract}

Keywords: Electric Bike, Solar Panel, Inverter

\begin{abstract}
ABSTRAK
Penelitian ini betujuan untuk merancang sistem pengisian baterai menggunakan inverter sebagai penyedia energi listrik pada SLN, mengetahui kinerja dan efektifitas pengisian baterai menggunakan inverter dibandingken dengan sistem yang telah terpasang. Metode yang digunakan dalam penelitian ini adalah Research and Development dengan mengembangkan sistem charging baterai menggunakan inverter pada sepeda listrik niaga (SLN) yang telah dibuat. Hasil penelitian menunjukkan pengisian baterai pada Sepeda Listrik Niaga memiliki nilai yang lebih efektif dan proses pengisian baterai yang lebih cepat menggunakan inverter pada solar panel sebesar 300wp yang digunakan sebagai supply energi utamanya. Sistem pengisian baterai menggunakan inverter sebagai penyedia energi listrik pada SLN memerlukan waktu sebesar 10,182 jam untuk mengisi baterai 48 volt sampai penuh. Sehingga proses pengisian baterai menggunakan inverter lebih efektif dibandingken dengan sistem yang sebelumnya telah terpasang dengan rasio perbandingan pengisian baterai sebesar $1: 2,94$ atau tiga kali lebih efektif dibanding sistem sebelumnya.
\end{abstract}

Kata Kunci: Sepeda Listrik, Solar Panel, Inverter

\section{PENDAHULUAN}

Teknologi hijau (Green Technology) menjadi solusi bagi berbagai kerusakan lingkungan akibat pemanfaatan sumber daya alam berbahan dasar fosil. Teknologi hijau merupakan cara untuk menghasilkan energi dan/atau produk yang tidak mencemari atau meracuni lingkungan hidup. Energi hijau merupakan energi yang dihasilkan oleh sumber alam seperti cahaya matahari, air, angin dan pemanasan geotermal. Sumber alam tersebut merupakan energi alternatif selain energi konvensional yang berbahan batubara dan minyak bumi.
Perkembangan sistem penyediaan energi alternatif saat ini terus dilakukan, mulai dari pemanfaatan sumber daya alam berupa sinar matahari, angin, panas bumi, ombak dan lain sebagainya sebagai energi dasar yang akan dikonversi menjadi energi listrik untuk memenuhi kebutuhan manusia akan energi listrik. Sistem panel surya yang saat ini mulai banyak diterapkan di berbagai tempat di Indonesia, terutama yang belum terjangkau oleh penyedia listrik PLN menjadi sebuah solusi untuk kebutuhan energi listrik di masyarakat daerah tersebut. Penggunaan panel surya sebagai penyedia enegi listrik untuk menggantikan penggunaan energi fosil sebagai 
bahan bakar kendaraan bermotor terus berkembang, mulai dari mobil bertenaga surya maupun mobil hybrid, motor dan sepeda listrik sebagai solusi untuk mengurangi konsumsi energi berbahan dasar fosil yang saat ini menjadi penyebab pencemaran lingkungan.

Fakultas Teknik Universitas Negeri Yogyakarta dalam rangka turut mendukung terciptanya sarana transportasi bersih dan ramah lingkungan terus melakukan penelitian yang menghasilkan alat transportasi berbahan dasar energi alternatif seperti mobil listrik, mobil hybrid dan sepeda listrik. Sepeda niaga roda tiga atau lazim juga disebut dengan gerobak niaga saat ini masih popular digunakan oleh para pedagang kecil untuk menjajakan barang dagangannya dengan cara berkeliling. Gerobak niaga ini masih dijalankan dengan cara mengayuh. Berawal dari hal tersebut kemudian muncul ide untuk mendesain dan mengembangkan sebuah gerobak niaga yang ramah lingkungan (Green Wagon atau Green Vehicle). Sepeda niaga roga 3 ini digerakkan dengan tenaga listrik atau disebut dengan Sepeda Listrik Niaga (disingkat SLN). Green Wagon ini tidak memerlukan bahan bakar minyak dan gas dalam pengoperasionalnya sehingga bebas emisi karbon dan tidak bising (ramah lingkungan). Sayangnya sepeda listrik niaga ini masing belum lazim dan popular di Indonesia.

Lebih jauh lagi, jika dilihat dari kemampuan daya motor dan desain bak, sebenarnya SLN ini tidak hanya diperuntukkan khusus bagi para pedagang kecil keliling saja. SLN ini sesungguhnya sebuah kendaraan angkut elektrik serbaguna. Artinya, kendaraan listrik roda 3 ini dapat digunakan sebagai alat angkut barang dan benda apapun selama bobot dan volumenya tidak melebihi batas yang diizinkan. Jadi selain para pedagang keliling, para tukang sampah, tukang jahit/sol sepatu, para petani untuk mengangkut hasil sawahnya, dan lain-lain bisa menggunakan SLN ini.

Daya motor penggerak pada SLN ini sebesar 500 Watt, dengan tegangan kerja 48 Volt. Kendaraan ini bisa dijalankan pada dua mode, yaitu mode maju dan mundur dengan kendali tombol yang bekerja secara elektronik. Kendaraan ini juga mempunyai 2 tingkat kecepatan, yaitu low (L) dan high $(\mathrm{H})$, yang dikendalikan dengan transmisi manual atau reduksi roda gigi. Pengoperasian transmisi dilakukan dengan tuas/ tongkat yang digerakkan dengan tangan pengemudi. Batere yang terpasang adalah 4 x 12 V $32 \mathrm{AH}$. Dengan charger yang banyak dijual di pasaran dengan kapasitas arus sampai dengan 10A pada mode 48 Volt, batere akan terisi penuh membutuhkan waktu kurang lebih 5 jam. Jika menggunakan charger yang lebih bagus, pada arus $20 \mathrm{~A}$, maka batere akan penuh dalam 1.5 jam.

Kemudian performa SLN generasi kedua ini ditambah dengan solar panel (200Wp) yang dipasang di tutup atas kendaraan. Solar panel ini digunakan untuk mencharge battery 48 volt jika dioperasikan pada siang hari. Diharapkan dengan tambahan sistem solar panel ini dapat meningkatkan performa secara umum dari SLN. Saat ini, SLN belum diimplementasikan maupun diuji kemampuannya. Implementasi dan pengujian SLN ini digunakan pada moda transportasi barang di Fakultas Teknik Universitas Negeri Yogyakarta.

Solar panel yang telah terpasang pada sistem penyedia energi listrik SLN masih belum optimal. Saat ini kemampuan pengisian baterai sampai penuh memerlukan waktu yang cukup lama yaitu sampai 30 jam. Hal ini menjadi kendala untuk lebih mengefektifkan pemanfaatan energi surya sebagai bahan dasar penyediaan energi penggeraknya. Untuk itu perlu dikembangkan suatu sistem yang baru guna lebih mengefektifkan sistem panel surya yang telah terpasang pada SLN tersebut, salah satunya dengan sistem pengisian baterai menggunakan inverter.

\section{METODE}

Penelitian ini adalah penelitian pengembangan dimana Sepeda Listrik Niaga (SLN) yang telah dibuat akan dikembangkan pada sistem charging baterainya menggunakan inverter. 


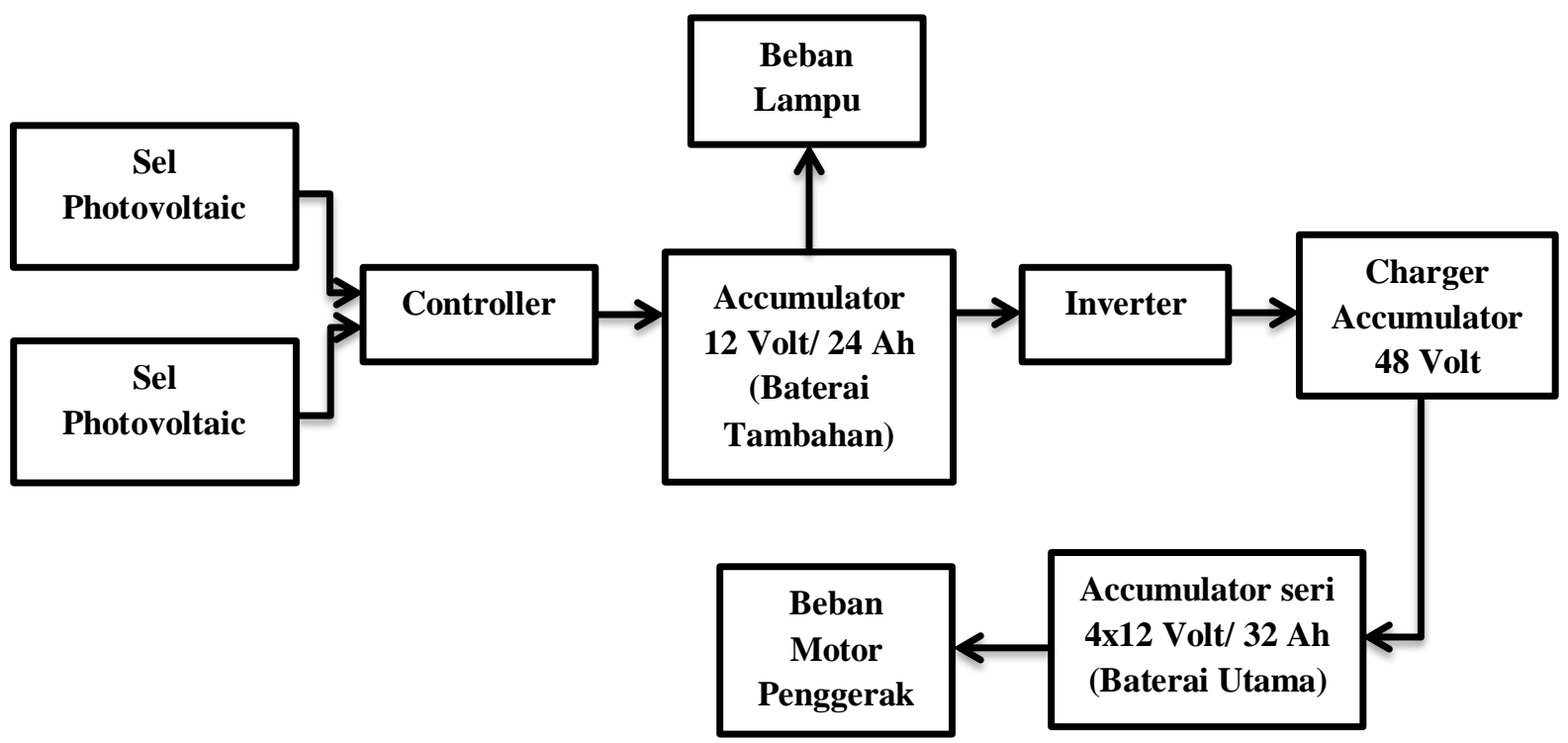

Gambar 1. Desain Penelitian

Penelitian ini dilaksanakan di Jurusan Pendidikan Teknik Elektro Fakultas Teknik Universitas Negeri Yogyakarta. Penelitian dilakukan mulai bulan april sampai oktober 2017. Objek yang diteliti berupa sebuah unit Sepeda Listrik Niaga (SLN) roda tiga dengan sumber energi listrik berasal dari energi matahari yang dikonversi ke energi listrik menggunakan panel surya yang disimpan dalam sebuah baterai. Arus pengisian baterai utama berasal dari dua sumber yaitu charging langsung dari unit solar panel dan charging tambahan dari solar panel yang dilengkapi dengan unit inverter. Penggerak yang digunakan berupa motor BLDC yang dikendalikan oleh sebuah controller.

Data yang diambil berupa tegangan dan arus pada output solar panel, tegangan dan arus pada output controller solar panel, tegangan dan arus output inverter, kemudian dihitung besarnya daya yang didapatkan. Waktu charging dan kapasitas pada baterai utama dan baterai tambahan diambil dari mulai baterai kosong sampai baterai terisi penuh.

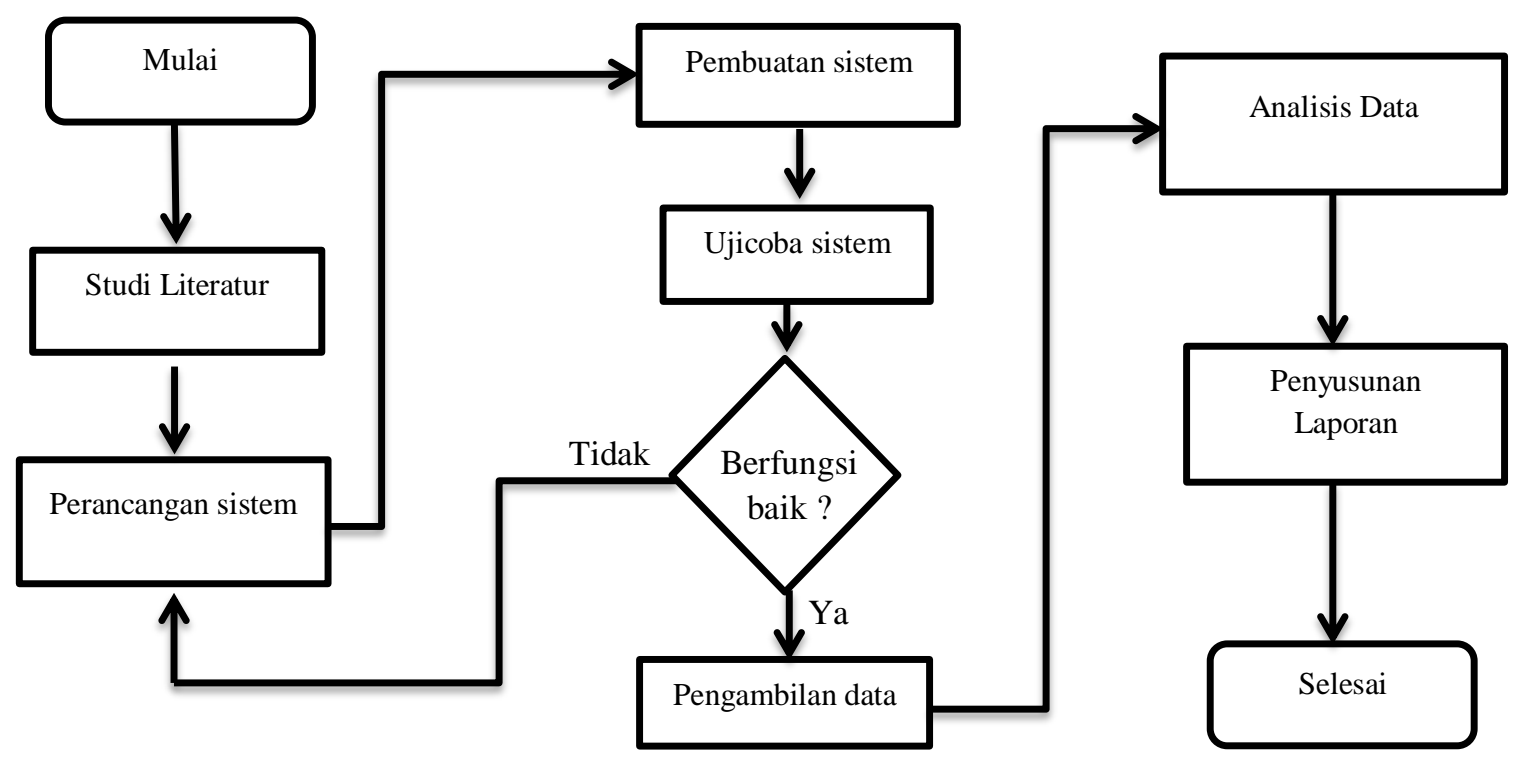

Gambar 2. Prosedur Penelitian 


\section{HASIL DAN PEMBAHASAN}

Berdasarkan Tugas Akhir yang disusun oleh Irfan Jati Kusuma dalam pengembangan sepeda listrik niaga sebelumnya diperoleh data dari hasil pengujian pengisian baterai menggunakan charger 48 Volt dengan sumber listrik PLN diperoleh data dalam tabel 1.

Tabel 1. Pengisian baterai menggunakan charger 48 Volt dengan sumber listrik PLN

\begin{tabular}{|c|c|c|}
\hline Jam & $\begin{array}{c}\text { Tegangan } \\
\text { Pengisian Baterai (V) }\end{array}$ & $\begin{array}{c}\text { Arus Pengisian } \\
\text { ke Baterai (A) }\end{array}$ \\
\hline $08: 00$ & 48,9 & 1,92 \\
\hline $09: 00$ & 49,8 & 1,92 \\
\hline $10: 00$ & 52,2 & 1,92 \\
\hline $11: 00$ & 54,8 & 1,92 \\
\hline $12: 00$ & 56,3 & 1,92 \\
\hline $13: 00$ & 58,1 & 1,92 \\
\hline $14: 00$ & 59 & 1,92 \\
\hline $14: 15$ & 52 & 0 \\
\hline
\end{tabular}

Berdasarkan data pengisian baterai dengan charger PLN $48 \mathrm{~V}$ pada tabel 1, untuk mengisi baterai dari kondisi low sampai kondisi full dibutuhkan waktu selama 6,25 jam. Arus pengisian stabil pada 1,92 A dan tegangan pengisian dengan range tegangan antara $48,9 \mathrm{~V}$ sampai 59 V. Setelah kondisi baterai penuh, maka lampu indikator pada charger 48 volt akan berubah warna dari merah menjadi hijau. Pada kondisi baterai penuh arus pengisian menunjukkan 0 A yang menandakan sudah tidak ada arus yang mengalir ke baterai dan tegangan baterai menjadi $52 \mathrm{~V}$.

Besarnya Ah pengisian baterai menggunakan charger 48 volt pada sumber listrik PLN adalah sebagai berikut :

Ah pengisian $=1,92 \mathrm{Amp} \times 6,25 \mathrm{jam}=12 \mathrm{Ah}$

Pada penelitian sebelumnya, dengan pengisian baterai dengan menggunakan sistem SSC yang disusun oleh Irfan diperoleh data pengisian selama 6 hari dilihat pada gambar 3 .

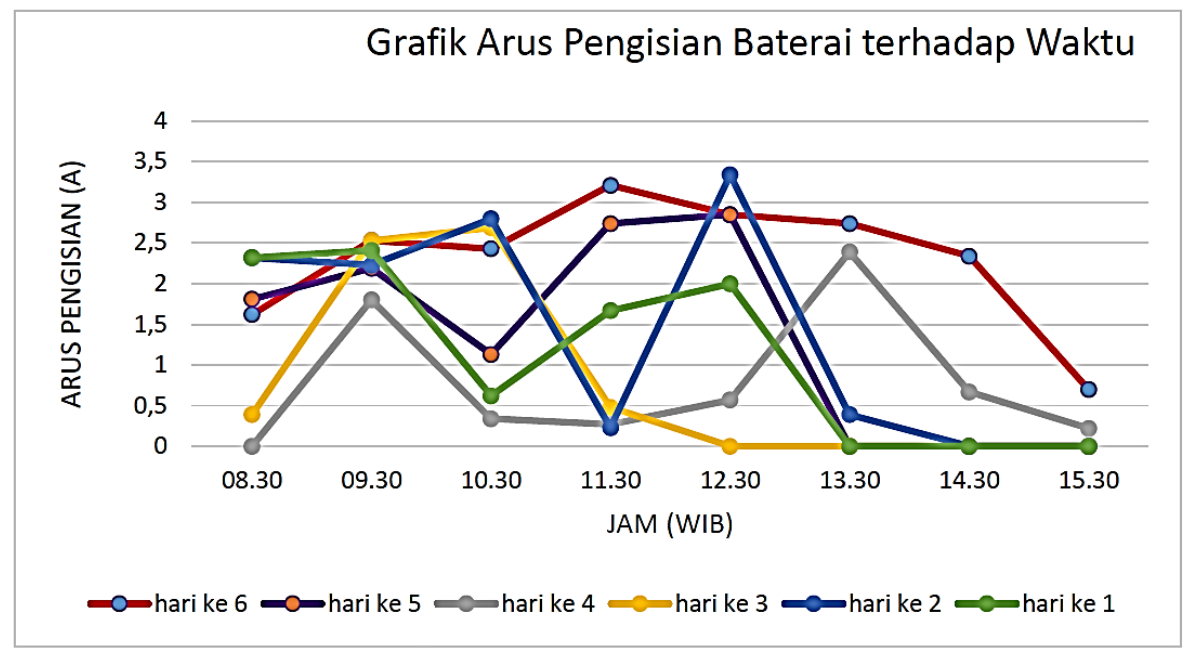

Gambar 3. Proses pengisian baterai menggunakan sistem SSC

Dari grafik diatas dapat dilihat bahwa proses pengisian baterai menggunakan SCC 48
$\mathrm{V}$ step down pada musim hujan di bulan november membutuhkan waktu selama 30 jam 
untuk mengisi baterai dari kondisi low sampai kondisi baterai full. Sistem pengisian menggunakan SCC 48 Volt step down pada pengembangan sebelumnya masih memiliki kekurangan yaitu proses pengisian baterai tergolong lama.
Tahap awal pengembangan dengan mengambil data pengisian baterai $12 \mathrm{~V} 10 \mathrm{Ah}$ dengan menggunakan solar panel $100 \mathrm{wp}$ melalui Solar Charge Controller 30 Ampere.

Tabel 2. pengisian baterai $12 \mathrm{~V} 10$ Ah dengan menggunakan solar panel 100wp melalui Solar Charge Controller 30 Ampere

\begin{tabular}{|c|c|c|c|c|c|c|}
\hline \multirow{2}{*}{ No } & \multirow{2}{*}{$\begin{array}{l}\text { Waktu } \\
\text { (Mnt) }\end{array}$} & \multirow{2}{*}{ Kondisi } & \multicolumn{2}{|c|}{ Tagangan } & \multicolumn{2}{|c|}{ Arus } \\
\hline & & & Output PV & Output SCC & Output Panel & Output SCC \\
\hline 1 & 0 & Berawan & $12.5 \mathrm{~A}$ & $12 \mathrm{~A}$ & $0.60 \mathrm{~A}$ & $0.55 \mathrm{~A}$ \\
\hline 2 & 5 & Berawan & $12 \mathrm{~V}$ & $12 \mathrm{~V}$ & $0.23 \mathrm{~A}$ & $0.20 \mathrm{~A}$ \\
\hline 3 & 10 & Berawan & $12.5 \mathrm{~V}$ & $12.5 \mathrm{~V}$ & $0.78 \mathrm{~A}$ & $0.78 \mathrm{~A}$ \\
\hline 4 & 15 & Berawan & $12.5 \mathrm{~V}$ & $12.5 \mathrm{~V}$ & $0.79 \mathrm{~A}$ & $0.78 \mathrm{~A}$ \\
\hline 5 & 20 & Berawan & $13 \mathrm{~V}$ & $13 \mathrm{~V}$ & $0.79 \mathrm{~A}$ & $0.79 \mathrm{~A}$ \\
\hline 6 & 25 & Berawan & $13 \mathrm{~V}$ & $13 \mathrm{~V}$ & $0.88 \mathrm{~A}$ & $0.88 \mathrm{~A}$ \\
\hline 7 & 30 & Berawan & $14 \mathrm{~V}$ & $14 \mathrm{~V}$ & $1.16 \mathrm{~A}$ & $1.66 \mathrm{~A}$ \\
\hline 8 & 35 & Berawan & $14 \mathrm{~V}$ & $14 \mathrm{~V}$ & $1.2 \mathrm{~A}$ & $1.2 \mathrm{~A}$ \\
\hline 9 & 40 & Berawan & $14 \mathrm{~V}$ & $14 \mathrm{~V}$ & $1.56 \mathrm{~A}$ & $1.56 \mathrm{~A}$ \\
\hline 10 & 45 & Berawan & $14 \mathrm{~V}$ & $14 \mathrm{~V}$ & $2.14 \mathrm{~A}$ & $2.16 \mathrm{~A}$ \\
\hline 11 & 50 & Berawan & $14 \mathrm{~V}$ & $14 \mathrm{~V}$ & $2.7 \mathrm{~A}$ & $2.64 \mathrm{~A}$ \\
\hline 12 & 55 & Berawan & $14 \mathrm{~V}$ & $14 \mathrm{~V}$ & $2.4 \mathrm{~A}$ & $2.4 \mathrm{~A}$ \\
\hline 13 & 56 & Berawan & $19 \mathrm{~V}$ & $14 \mathrm{~V}$ & $0.8-1 \mathrm{~A}$ & $0.8-1 \mathrm{~A}$ \\
\hline
\end{tabular}

Tabel diatas menunjukkan proses pengisian baterai 12 Volt 10 Ah yang akan digunakan sebagai baterai antara yang diisi menggunakan solar panel 100 wp memiliki proses pengisian sebesar 55 menit dengan rentang arus pengisian antara 0,2 sampai 2,64 Ampere pada kondisi berawan.

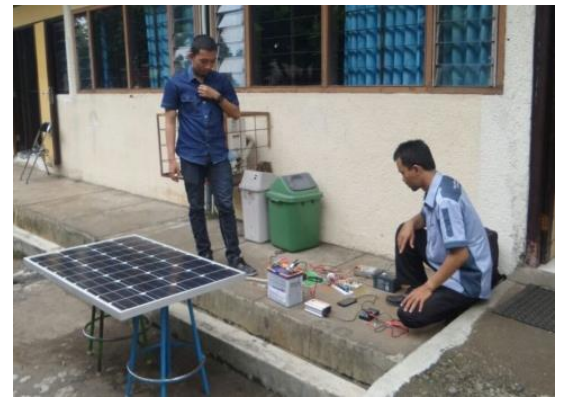

Gambar 4. Pengambilan data pengisian aki 12 volt 
Proses pengambilan data dilanjutkan dengan mengisi aki 48 Volt yang terdiri dari aki 12 volt 4 buah yang dirangkai secara seri dari aki 12 volt 10 Ah menghasilkan data seperti tabel 3 .

Tegangan baterai 12 Volt 10 Ah saat terisi penuh terukur sebesar 12.2 Volt dengan tegangan baterai kosongnya sebesar 11 Volt. Sedangkan tegangan baterai 48 volt saat kosong sebesar 45 Volt dan tegangan batterai setelah charging dilakukan sebesar 50 Volt. Hal ini menunjukkan bahwa terdapat peningkatan tegangan baterai 48 volt sebesar 5 volt setelah di-charge menggunakan baterai 12 volt $10 \mathrm{Ah}$ yang menunjukkan bahwa pengisian baterai 48volt telah dapat dilakukan.

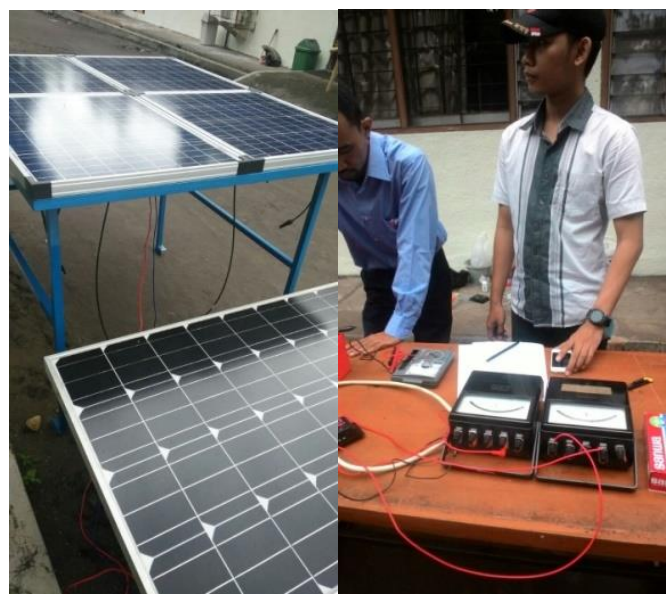

Gambar 5. Pengambilan data untuk pengisian menggunakan solar panel $300 \mathrm{wp}$

Tabel 3. Pengisian aki 48 Volt dari aki 12 volt $10 \mathrm{Ah}$

\begin{tabular}{|c|c|c|c|c|c|}
\hline NO & $\begin{array}{c}\text { Waktu } \\
\text { (Menit) }\end{array}$ & Arus Aki & $\begin{array}{c}\text { Tegangan } \\
\text { Input }\end{array}$ & $\begin{array}{c}\text { Tegangan } \\
\text { Output }\end{array}$ & $\begin{array}{c}\text { Arus } \\
\text { Output }\end{array}$ \\
\hline 1 & 0 & $9.5 \mathrm{~A}$ & $10 \mathrm{~V}$ & $60 \mathrm{~V}$ & $1.75 \mathrm{~A}$ \\
\hline 2 & 5 & $9.7 \mathrm{~A}$ & $10 \mathrm{~V}$ & $60 \mathrm{~V}$ & $1.75 \mathrm{~A}$ \\
\hline 3 & 10 & $9.8 \mathrm{~A}$ & $10 \mathrm{~V}$ & $60 \mathrm{~V}$ & $1.75 \mathrm{~A}$ \\
\hline 4 & 15 & $9.9 \mathrm{~A}$ & $10 \mathrm{~V}$ & $60 \mathrm{~V}$ & $1.75 \mathrm{~A}$ \\
\hline 5 & 20 & $10 \mathrm{~A}$ & $9.5 \mathrm{~V}$ & $57.5 \mathrm{~V}$ & $1.75 \mathrm{~A}$ \\
\hline 6 & 25 & $10.1 \mathrm{~A}$ & $9 \mathrm{~V}$ & $60 \mathrm{~V}$ & $1.75 \mathrm{~A}$ \\
\hline 7 & 30 & $10.2 \mathrm{~A}$ & $9 \mathrm{~V}$ & $57.5 \mathrm{~V}$ & $1.75 \mathrm{~A}$ \\
\hline 8 & 35 & $10.4 \mathrm{~A}$ & $8.8 \mathrm{~V}$ & $56 \mathrm{~V}$ & $1.75 \mathrm{~A}$ \\
\hline
\end{tabular}

Proses pengambilan data dilanjutkan dengan merangkai seluruh solar panel secara paralel menjadi 300 wp dengan menggunakan solar charge controller 30 Amp melalui inverter dan charger 48 volt untuk mengisi aki 48 volt dengan rangkaian pengujian sebagai berikut :

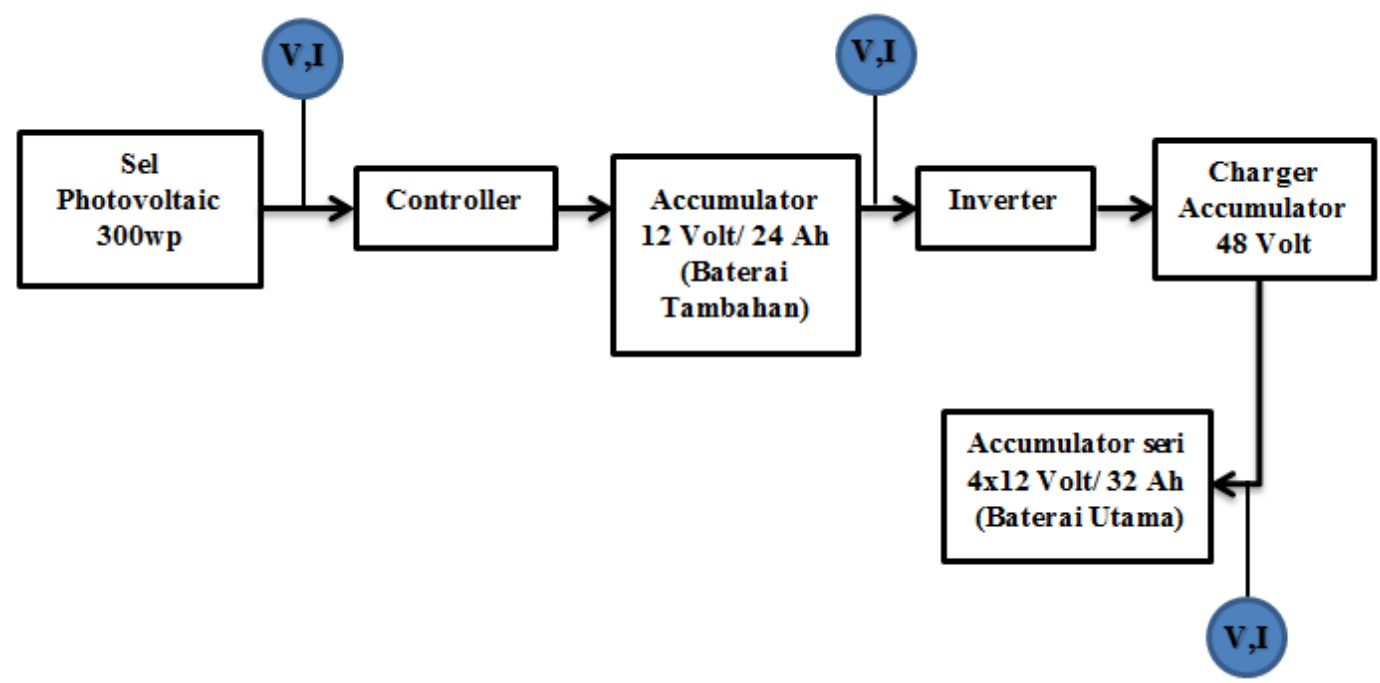

Gambar 6. Alur proses pengambilan data penelitian 
Tegangan dan arus diambil pada keluaran solar panel, keluaran aki 12 volt $10 \mathrm{Ah}$ dan keluaran charger 48 volt menghasilkan data sebagai berikut :

Tabel 4. Pengisian aki 48 Volt dari aki 12 volt 10 Ah menggunakan inverter dan solar panel 300 wp

\begin{tabular}{|c|c|c|c|c|c|c|}
\hline Waktu & V PV & I PV & V Bat. 12 V & I Out Bat. 12 V & I Bat $48 \mathrm{~V}$ & V Bat. 48 \\
\hline 0 & 12 & 2.5 & 12 & 8 & 1.75 & 48 \\
\hline 5 & 12 & 4.5 & 12 & 8.4 & 1.75 & 49 \\
\hline 10 & 12 & 4.5 & 12 & 8.4 & 1.75 & 49 \\
\hline 15 & 12 & 5.5 & 11.3 & 8.5 & 1.75 & 50 \\
\hline 20 & 11.5 & 4.5 & 11.3 & 8.6 & 1.72 & 50 \\
\hline 25 & 11.5 & 4.5 & 11.1 & 8.65 & 1.72 & 50 \\
\hline 30 & 11.3 & 5.5 & 11 & 8.8 & 1.72 & 50 \\
\hline 35 & 11.3 & 6 & 11 & 9 & 1.72 & 50 \\
\hline 40 & 12 & 12 & 11 & 9.8 & 1.72 & 50 \\
\hline 45 & 13 & 10 & 12 & 7.7 & 1.72 & 49 \\
\hline 50 & 17 & 14 & 13 & 7 & 1.72 & 49.8 \\
\hline 55 & 16 & 13 & 13 & 7 & 1.72 & 49.8 \\
\hline 60 & 13 & 9 & 12 & 8.1 & 1.72 & 50 \\
\hline 65 & 12 & 4.5 & 11.8 & 8.2 & 1.72 & 50 \\
\hline 70 & 12 & 5 & 11.5 & 8.2 & 1.72 & 50 \\
\hline 75 & 12 & 5 & 11.5 & 8.4 & 1.72 & 50 \\
\hline 80 & 11.5 & 5.5 & 11 & 8.8 & 1.72 & 50 \\
\hline 85 & 12 & 2.5 & 12 & 8 & 1.72 & 49 \\
\hline 90 & 12.5 & 11 & 12 & 8.1 & 1.72 & 50 \\
\hline 95 & 12 & 6 & 12 & 8.4 & 1.72 & 50 \\
\hline 100 & 12.2 & 11 & 12 & 8.3 & 1.72 & 50 \\
\hline 105 & 12 & 8 & 12 & 8.2 & 1.72 & 50 \\
\hline 110 & 11 & 2.5 & 11 & 9.9 & 1.72 & 50 \\
\hline
\end{tabular}

Berdasarkan tabel diatas, dapat dihasilkan grafik tegangan dan arus solar panel $300 \mathrm{wp}$, grafik tegangan dan arus baterai 12 volt dan grafik pengisian aki 48 volt sebagai berikut :

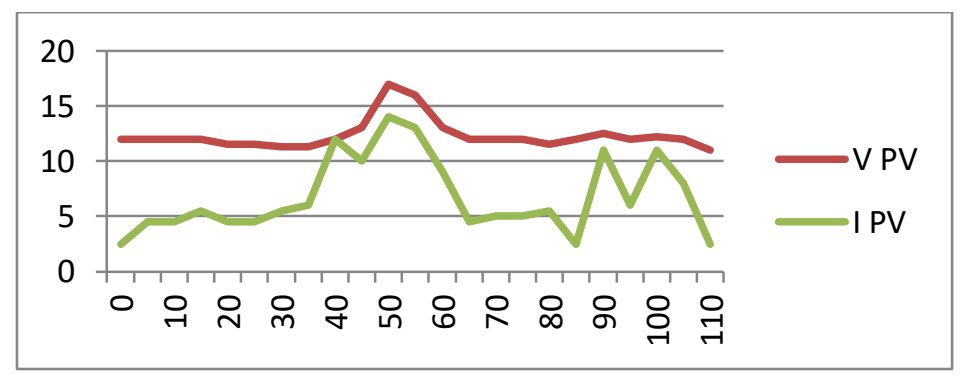

Gambar 7. Grafik tegangan terhadap arus pada panel surya $300 \mathrm{wp}$ 


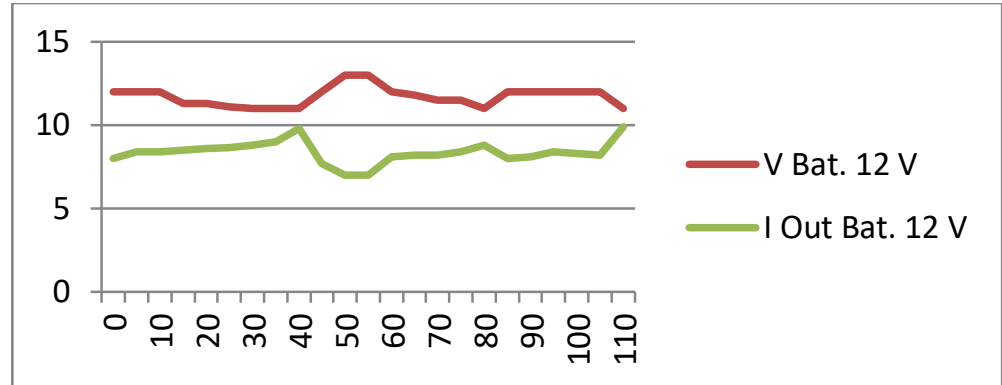

Gambar 8. Grafik tegangan terhadap arus pada baterai 12 volt $10 \mathrm{Ah}$

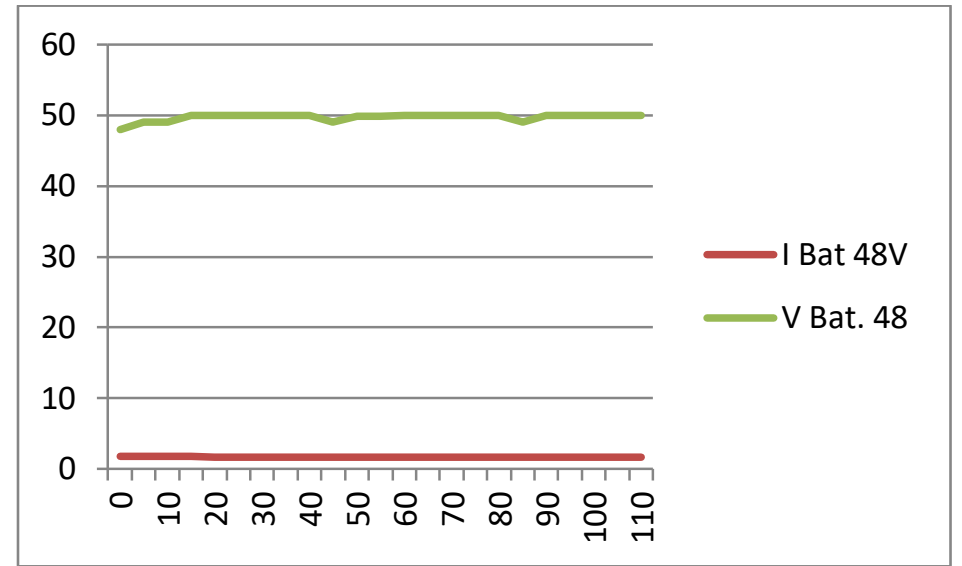

Gambar 9. Grafik tagangan dan arus pada charger 48 volt

Hasil pengujian menunjukkan bahwa charging menggunakan inverter lebih efektif dibanding dengan sistem charging sebelumnya dilihat dari arus pengisian yang mengalir pada baterai stabil sebesar $1,72 \mathrm{~A}$ sebanding dengan arus charging menggunakan Daya Listrik PLN yaitu sebesar 1,92 A. Sehingga dapat dihitung lama waktu pengisian baterai menggunakan inverter sebagai berikut :

$$
\begin{aligned}
\text { Waktu pengisian } & =\frac{12 \mathrm{Ah}}{1,72 \mathrm{Amp}}= \\
6,976 \mathrm{jam} & \approx 7 \mathrm{jam}
\end{aligned}
$$

Dalam proses pengisian baterai 48 volt dalam kondisi berawan terdapat jeda sebesar 20 menit untuk setiap pengisian baterai selama 44 menit dari baterai 12 volt $10 \mathrm{Ah}$. Hal ini disebabkan baterai 12 volt 10 Ah telah habis digunakan untuk mengisi baterai 48 volt sehingga perlu pengisian ulang. Sebagai implikasinya waktu pengisian bertambah sebesar 20/44 menit atau 0,4545 kali dari pengisian secara kontinyu, sehingga waktu pengisian total dengan jeda 20 menit untuk pengisian baterai $10 \mathrm{Ah}$ sebesar :
Waktu pengisian total $=$

$$
7 \mathrm{jam} \times(1+0,4545)=10,182 \mathrm{jam}
$$

Waktu pengisian dengan menggunakan inverter ternyata lebih cepat dibanding dengan sistem sebelumnya. Dimana sistem sebelumnya sebesar 30 jam, sedangkan dengan sistem yang baru sebesar 10,182 jam hampir mendekati pengisian menggunakan daya listrik PLN.

\section{SIMPULAN}

Sistem pengisian baterai menggunakan inverter sebagai penyedia energi listrik pada SLN disusun dengan menggunakan solar panel sebesar 300 wp yang dirangkai secara paralel untuk mengisi baterai 12 volt 10 Ah yang kemudian diinverterkan ke 220 volt AC untuk mengisi baterai 48 volt menggunakan charger 48 volt.

Sistem pengisian baterai menggunakan inverter sebagai penyedia energi listrik pada SLN memerlukan waktu sebesar 10,182 jam untuk mengisi baterai 48 volt sampai penuh. Sistem ini lebih cepat dibanding pengisian 
sebelumnya yang memerlukan waktu sebesar 30 jam.

Proses pengisian baterai menggunakan inverter lebih efektif dibandingken dengan sistem yang sebelumnya telah terpasang dengan rasio perbandingan pengisian baterai sebesar 1 : 2,94 atau tiga kali lebih efektif dibanding sistem sebelumnya.

\section{DAFTAR RUJUKAN}

Bambang Sujanarko. 2010. Metode Sinkronisasi Inverter Satu Fase Dengan Jaringan Listrik Yang Terdistorsi. TELKOMNIKA Vol. 8, No. 1, April 2010.

Dian Sarita Widaringtyas, dkk. (Tanpa Tahun). Inverter 15v Dc-220v Ac Berbasis Tenaga Surya Untuk Aplikasi Single Point Smart Grid. Jurusan Teknik Elektro Fakultas Teknik Universitas Brawijaya

Fadhli MR. 2010. Rancang Bangun Inverter 12v DC Ke 220v AC Dengan Frekwensi $50 h z$ dan Gelombang Keluaran Sinusoidal. Program Studi Teknik Elektro Fakultas Teknik Universitas Indonesia.
Hasyim Asy'ari, dkk. 2014. Desain Sepeda Statis Dengan Generator Magnet Permanen Sebagai Penghasil Energi Listrik Yang Ramah Lingkungan. Prosiding Seminar Nasional Aplikasi Sains \& Teknologi (SNAST) 2014

Irfan Jati Kusuma. 2016. Solar Charge Controller 48 V (Step Down) Dengan Metode MPPT (Maximum Power Point Tracking). Program Studi Teknik Elektro D3 Fakultas Teknik Universitas Negeri Yogyakarta.

Irwan Sukma Darmawan. 2012. Pengembangan Inverter 12VDC ke $220 \mathrm{AC} 50 \mathrm{~Hz}$ Dengan Penguat Akhir H-Bridge Mosfet. Departemen Teknik Elektro Universitas Indonesia.

Rico Alvin dan Ibnu Kahfi Bachtiar. 2016. Perancangan Inverter Untuk Pembangkit Listrik Tenaga Surya (Plts) Skala Rumah Tangga. Jurnal Fakultas Teknik Universitas Maritim Raja Ali Haji.

Yustinus Andrianus Sinaga. 2016. Rancang Bangun Inverter 1 Phasa Dengan Kontrol Pembangkit Pulse Width Modulation (PWM). Fakultas Teknik Universitas Lampung. 